\title{
The 'War on Drugs' Concept as the Basis for Combating Drugs in the Western Hemisphere
}

Arkadiy Alekseevich Eremin, Oleg Konstantinovich Petrovich-Belkin

The article attempts to critically evaluate a controversial transnational phenomenon in the Western hemisphere, known as the 'War on Drugs'. Started by Richard Nixon to regain the support of his electorate, it has continued to dominate anti-drug policies in the Americas until now. In this article, the authors conduct a thorough analysis of all the traits of this concept in relation to the effectiveness and capability of limiting drug production and supply as well as countering drug-related organized crime. It also describes the role and place of the 'War on Drugs' in the structure of modern academic knowledge. In the attempt to assess the outcomes of the implementation of coercive tactics typical for the 'War on Drugs', the article also tries to answer the essential question of whether traditionally harsh methods of this concept were truly meant to be aimed at suppressing transnational drug trade or were merely a way for political elites to meet certain personal agenda. The paper recommends several potential changes that are necessary to be introduced to successfully relaunch and reestablish the system of combating illicit drug trade in the Western hemisphere.

Keywords: war on drugs, anti-drug policies, Western hemisphere, transnational drug trade

Arkadiy Alekseevich Eremin, Oleg Konstantinovich Petrovich-Belkin. The 'War on Drugs' Concept as the Basis for Combating Drugs in the Western Hemisphere. Central European Journal of International and Security Studies I3, no. 2: 3I-47.

(C) 2019 CEJISS. Article is distributed under Open Access licence: Attribution NonCommercial 3.0 Unported (cc by-nc 3.0). 
Before going further into the subject of the article, it would be essential to mention that the concept of the 'War on Drugs' represents mostly a Western Hemisphere phenomenon since the wide empirical discussion on this matter generally belongs to the Western academia and

CEIISS the country of its origin and its most active apologist were the United 2/20I9 States of America. Given the specificity of the geopolitical situation during the Cold War, it is only logical that this concept was developed in the framework of United States domestic and foreign policies.

The 'War on Drugs' is a political concept introduced during the presidency of Richard Millhouse Nixon, who at the time was 'knee deep' in political and social instability in the United States. A highly unpopular and costly war overseas and a lack of significant progress in fighting communism in South-East Asia alongside with the blooming culture of protest at home created harsh circumstances that made authorities look for options. American citizens were experiencing a lack of purpose and motivation - with every year it became obvious that communism was no longer the major source of concern for ordinary citizens, who were becoming more preoccupied with civil rights, equality and quality of life. This trend peaked during the I960's, but never lost its momentum, thus resulting in a massive cultural shift in the U.S. society. It no longer was possible to occupy people's minds with the 'red threat' in order to distract them from the aspiration for profound societal changes.

During that very period the United States of America had already become a target for a rapidly developing illicit business called transnational drug trade. Before the I96o's the main drug to be smuggled into the U.S. was marijuana, which had steady demand and brought a considerable amount of profit; however, it was far from the kind of money modern drug trade accumulates. The biggest problem of marijuana trade was predetermined by the relatively low ratio of price per pound, which made most active drug traffickers look for other possibilities. The perfect drug turned out to be cocaine - small packages were easier to smuggle across the border and at the same time brought significantly larger revenue. Unlike heroin, the source of which was generally too far from the U.S., the Andes were quite close. This allowed drug smugglers to build supply chains of various complexity levels - from smuggling small packages of cocaine in carry-ons during regular civil aviation flights to using private planes and even submarines to transport tons of illegal product. The late 6o's and 70's were the periods when 
the use of drugs, cocaine in particular, skyrocketed to unprecedented scales and from that time forward it only kept growing, leading to the crack cocaine epidemic in the 80's. ${ }^{1}$

Under Nixon the drug problem had already bloomed to such a degree that it was no longer possible to ignore. Officially what caused president to enforce a full-scale crack-down on drugs was the fact that a significant percentage of soldiers who came back from Vietnam were reported to have acquired heroin addiction. Eventually in his State of the Union speech in 197I Richard Nixon declared the 'War on Drugs', which predetermined the nature of future anti-drug strategies. However, such a potent promise to fight drug trade with all the means available did not prove effective in the long-term - statistics show that the harshness of the anti-drug measures and massive incarcerations had no proven positive influence on both growing offer and demand. ${ }^{2}$ Moreover, the very concept introduced by Nixon over the years had received heavy criticism from both expert and academic communities on multiple occasions.

The main hypothesis (research question) of this article is that the 'War on Drugs' concept is evidently unfit on multiple levels for successful resolution of the problem of drugs both on a national and regional scale. Moreover, the usage of its heritage undermines the process of conceptualization of new approaches and practices in the respective sphere. The authors conclude that, firstly, purely coercive methods of countering the drug trade and drug consumption are highly ineffective and often lead to quite opposite results and consequences. Second, through the years the concept evolved to serve mostly other U.S. foreign policy goals, such as containing the spread of communism in the Western Hemisphere and particularly in Latin America. Finally, nowadays the Western Hemisphere faces the objective need for a thorough update or even a radical reset of the conceptual framework in the sphere of countering the spread of illicit substances.

The structure of the article is defined by the targets of the research. The introductory part consists of a general introduction, a description of scientific methods used by authors and historiography of the problem. The main part of the research contains general description of the 'War on Drugs' concept, as well as the wide criticism of its main vulnerabilities and controversial points, such as the unbalanced nature of the anti-drug policy approaches, lack of dedication to the proclaimed targets and the evident intent of U.S. government to use this concept
Arkadiy

Alekseevich

Eremin

Oleg

Konstantinovich Petrovich-Belkin 
as a political tool in the struggle against the influence of the USSR in the Western Hemisphere. In the conclusion of the article, the authors summarize scientific findings that were the result of complex analysis of the respective topic.

CEJISS

2/20I9 Methods

In order to explain the reasons for the failure of the 'War on Drugs' to achieve any relative goals and to demonstrate why it had not experienced any significant changes over the years it was implemented, it is necessary to use a number of research methods, relevant to the analysis of this problem. This article has used a complex of general-theoretical methods of deduction, induction, generalization and synthesis. In addition, the methodological basis of the research includes the principles of historicism, scientific objectivity, reliability and system analysis. This has allowed for a comparative analysis of the values imposed by the concept of the 'War on Drugs' and its influence on the subsequent anti-drug policies in the hemisphere, as well as revealing its impact on the current state of the illicit transnational drug trade.

\section{Historiography}

The criticism of the 'War on Drugs' in the Western academic society has deep roots. This concept was designed without any regard to the scientific knowledge and was based solely on decisionmaker opinions and intuition. Among the U.S. researchers who touched upon the topic of combating illicit drugs in the Western hemisphere are Levine M., Dinges J., Regilme S., Booth M., Otterman M., Chin G., Stevens A., Werb D., Provine D., Scott P.D., McCoy A.W., Web G., McCoun R. and Reuter P.

Due to the specificity of the topic there is significantly less Russian research. Some of the studies were conducted by Martynov B.F., Andreeva A.A., Krupnov U. V. and Levinson L.S. Generally, the focus of Russian drug-related research is based more on the general aspect of the drug issue and anti-drug policies efficiency.

\section{General Criticism of the Concept}

The 'War on Drugs', being the primary reference point for decision and policy makers for several decades, was bound to be under careful and thorough consideration of multiple scientists, journalists and politicians. After years of research the point was finally made that the 
values brought up by this concept are in fact not capable of changing the situation with the drug-trade problem for the better. Vast criticism of the concept accelerated in the last decade, bringing up various argumentation. Virtually, we can outline two basic arguments that demonstrate how unfit the 'War on Drugs' is to serve as an effective basis for successful anti-drug policies.

The first argument is the claim that the values promoted by the "War on Drugs' lead to an unbalanced approach in countering drug traffic. The modern state of scientific and expert knowledge in terms of combating illicit drugs suggests that in order to ensure positive results, anti-drug policy should work both with drug supply and demand. However, in the example of the 'War on Drugs', instead of granting multifold efforts, it was only focused on coercive tactics, massive incarcerations, rigorous raids and seizures. All these measures predominantly affected low-level organized crime group members, mild offenders and people with no criminal record, when top level beneficiaries of the illicit business often remained untouched. At the same time, fighting the supply chain did little to control the ever-rising demand. Needless to say, drug trade is a phenomenon with deep social roots, so it is impossible to beat by almost completely ignoring its social component. ${ }^{3}$

The second argument is that on top of being faultily designed, the concept also helped pursue other targets of political origin - both internally and externally. Domestically, considering the uneasy political situation the Nixon administration was dealing with at the time, it is argued that the 'War on Drugs' provided a widely discontent public with a new target to draw their attention from the failures of the current government. In this regard it is important to mention that during Nixon's presidency, the 'Détente' between USSR and the United States was at its peak, so active struggle against the communist threat was back then on hold for the U.S. establishment (except for the highly unpopular war in Vietnam). This explains the rising attention of the American people towards internal politics, which predetermined such an internally-oriented usage of the 'War on Drugs' at the time.

With the developments in international politics and the end of the 'Détente', the concept of the 'War on Drugs' and its implementation changed accordingly. The intensiveness of combating drugs under such a concept rose proportionally due to the rise in conflict potential between the two superpowers, leading to a radical change in its use under president Reagan. During his office the relations between USA 
and USSR again struck its historic minimum, which determined the dominant priority of struggling communist influence over combating illicit drugs. Under the so-called Reagan doctrine, which determined a new, more aggressive framework of fighting communism, the 'War

CEJISS on Drugs' was soon imported to the other countries in the Western 2/20I9 hemisphere. ${ }^{4}$ Formally it was supposed to bring the fight to the original suppliers, helping to bring down the rates of drug-trade and drug-related crime. However, it served as a tool in consolidating U.S. political influence in Latin America and thus pushing the Soviet threat back. In those circumstances, 'War on Drugs' became secondary to the Cold War, meaning that in order to counter USSR political efforts it was habitual not only to ignore the drug trade issues in several countries, but even to encourage local communities who lived off drug production and smuggling just because it would help undermine the communist expanding influence. The most vivid example of such lack of dedication to pursue the principles of this concept was the case of Nicaragua, with the infamous 'Iran-Contras' affair and multiple attempts to portray Sandinistas as notorious drug smugglers. From the point of view of fighting drugs such actions seem inconsistent and even malicious; however, when taking into the consideration the influence of the Reagan doctrine and its impact on the national security strategies at the time, the vector of development of this concept becomes obvious. For instance, the 1987 United States national security strategy equated illicit drug trade to terrorism in terms of harm and thus priority, manifesting the need to fight it with the same set of tools, meaning mostly coercive and force-based approaches. ${ }^{5}$ The I988 revision of this document alongside with the need to fight the communist influence in the region postulated that the drug-trade revenue can be used to sponsor pro-Soviet insurgency movements that would be a threat to allied nations in the Western Hemisphere. ${ }^{6}$ Based on this, it is logical to assume that the most criticized trait of the 'War on Drugs' concept, being commitment to the force-based approaches, comes from this period in time and those documents oriented mostly towards the external policy.

After the end of the Cold War period the export of the "War on Drugs' concept intensified, taking a slightly different form. Under the proclaimed dedication to fight the drug-related organized crime groups, Washington was free to run attractive aid programs, which with the use of strict limitations were designed to shape regional bi- 
lateral agenda in a specific manner. In order to be subjected to such aid, countries had to agree on the approaches and security priorities that were imposed by Washington. Countries that did not fall in line with the general course of coercive anti-drug policies in return did not pass the certification process, which led to the risk of certain sanctions from the U.S. government. ${ }^{7}$

\section{An Unbalanced Approach}

Discussions over the ineffectiveness of the anti-drug measures promoted by the U.S.A. have occurred in the expert communities for a long time. However, the biggest and most evident proof of that is the annual drug trade and consumption statistics. ${ }^{8}$

The backbone of the 'War on Drugs' concept and its further embodiment in the form of anti-drug policies is the implementation of harsh enforcement tactics. These strategies consist of two main parts: massive incarcerations and seizures. Both components seem logical in the context of fighting drug-related organized crime groups, but its effectiveness can only be guaranteed as a part of a larger, more comprehensive set of measures. In the case of the 'War on Drugs', incarcerations and seizures were the predominant part of the whole strategy, which basically meant fighting drugs solely by force with no significant social support.

Nowadays most of the leading researchers who specialize in this topic agree on the fact that an attempt to resolve the skyrocketing rates of the drug trade in the U.S. by mostly using state-sanctioned violence was not only ineffective, but malicious as well. For instance, after the start of the 'War on Drugs' the price for most drugs drastically decreased, marking a substantial rise in supply of illicit substances. ${ }^{9}$ If anything, a straightforward crackdown made drug lords adapt by inventing creative ways to bypass the reach of law enforcement and on top of that to turn more aggressive, violent and unpredictable than ever. More than a trillion dollars spent on enforcing this policy over the years resulted in no significant cutdown on the rate of drug use and abuse among American citizens, ${ }^{\text {IO }}$ which remained steady with a minor adjustment accounting for the natural growth in U.S. population.

At the same time, the massive incarcerations predominantly target the offenders with minor non-violent crimes, when the notorious kingpins and drug lords remain intact. ${ }^{I I}$ This has in no way harmed the illicit drug trade. By some estimates the volume of this market has
Arkadiy

Alekseevich

Eremin

Oleg

Konstantinovich Petrovich-Belkin 
reached more than hundred billion dollars per year in the U.S. alone, and with that kind of money cartels keep finding hundreds of new candidates to run their day-to-day operations. Besides, it has been stated that spending time in correctional facilities does not positively affect

CEJISS the inmates - most of them use this time to acquire new connections 2/20I9 in the criminal world and regroup in order to rejoin the illicit businesses when they are out. ${ }^{12}$ Moreover, once a mild offender gets into the penitentiary system, his or her chances to reintegrate in society drastically decline, making organized crime the easiest and sometimes the only way for them to support themselves and their families. ${ }^{13}$ The same applies to the drug addicts, who get charged with possession of hard drugs and are also sent to jail - such a facility does not provide a healthy environment to overcome addiction, rather than to strengthen it. $^{\text {I4 }}$

Such an approach is not only obviously ineffective, but also violates fundamental human rights. Massive incarcerations among young people and minorities only lead to the social exclusion of these population groups, which in return only aggravates the issue of drug-related crime. As a result, racially biased selective justice, disproportionately strict prosecutions for even minor drug-related offences and various imperfections of the US penitentiary system as well as other human rights violations formed a sui generis vicious circle that deprived these people of any social alternative.

\section{Different Political Agenda}

The fact that anti-drug policies that followed the introduction of the 'War on Drugs' concept were rather based on subjective opinions and outdated practices than on scientific knowledge does not prove ill intent. It wouldn't have been the first time for governmental policies to be ineffective and bias is not always intentional. Thus, it would seem very possible that inefficiency of these policies was the result of imperfect knowledge available in this specific sphere.

However, such an explanation would be viable if the government of the United States over the decades had realized that the current anti-drug course was not providing proper results. Statistics evidently demonstrate that the full-scale crackdown on narcotics as well as on drug addicts showed no positive changes in relation to combating drug trade and drug-related crime. In these circumstances one is expected to rethink the current approach and try to adjust it accordingly. Need- 
less to say, that was not the case with the government of the United States - instead of critical assessment of the concept, different administrations left doctrinal basis of the 'War on Drugs' mostly intact. Some changes were to happen during the presidency of Bill Clinton, but his sudden impeachment brought an end to that, giving way to a new wave of conservative policies and programs introduced by G.W. Bush. The American establishment did not just ignore the rising tide of criticism towards its anti-drug policies, it is even known to have concealed and discredited scientific research that proved the values and ideas of the 'War on Drugs' to be misleading. Among those was the research on the harm of marijuana, which proved that demonization of this light drug by the American authorities seriously lacked argumentation and the image that they thus created for the public was incorrect. ${ }^{15}$

This means that the U.S. government knew about the flaws in the drug countering strategies, which excludes the chance of a mistake. Nixon, the very president who started the 'War on Drugs', was even directly advised by a bipartisan commission to decriminalize marijuana, but his actual agenda was very different. ${ }^{16}$ The true intentions of this concept were revealed when John Ehrlichman, Nixon's top adviser in 1969-1972, confessed in his interview in 1994 to Dan Baum that the 'War on Drugs' was mostly pursuing pragmatic political interests:

The Nixon campaign in 1968, and the Nixon White House after that, had two enemies: the antiwar left and black people. You understand what I'm saying? We knew we couldn't make it illegal to be either against the war or black, but by getting the public to associate the hippies with marijuana and blacks with heroin, and then criminalizing both heavily, we could disrupt those communities. We could arrest their leaders, raid their homes, break up their meetings, and vilify them night after night on the evening news. Did we know we were lying about the drugs? Of course, we did. ${ }^{17}$

The country at the time was plunged into massive protests, which made it vitally important for U.S. government to search for ways to stabilize the situation by acquiring a legal toolset to easily target participants of the protest movements and minorities. While hippies became history, the original hate for racial minorities remained and was being cultivated throughout the following presidencies. According to 
research conducted by New York Times journalists, in the United States African American people are 4 times more likely to be arrested for use and possession of light drugs like marijuana than people with white skin, who generally just receive a warning. ${ }^{18}$ This trend of malicious

CEJISS association exists today and massively contributes to the high crim2/20I9 inalization and incarceration of minorities for doing light drugs or committing mild drug-related offences. This in return results in the rising rates of exclusion of these young people from society.

To a certain point, this information explains multiple design flaws of policies based on the 'War on Drugs' and their natural inability to successfully counter the rapidly developing drug trade. However, it leads us to the idea that U.S. government officials knowingly sabotaged federal anti-drug policies in exchange for internal political gains. And if with Nixon this malicious intent could be marked as his personal wrongdoing alongside with 'Watergate', the long-lasting heritage of this concept and its wide use in anti-drug decision making has made us consider the possibility that the U.S. government kept on using the 'War on Drugs' as a cover to ensure Washington's political interests in the Western Hemisphere.

\section{Cold War Priorities}

Having been set up and implemented during the Cold War, the "War on Drugs' concept was bound to have been affected by the spirit of that era, a part of which was the indisputable dominance of the ideological standoff with the Soviets. In this regard, it would not be a surprise that for most governmental agencies, fighting communism came before fighting drugs.

During the Cold War, the United States government (in order to oppose rapidly spreading communist influence in Latin America) was willing to support any military group or political regime, including most notorious dictatorships. However, not only did such political alliances harm the image of the U.S.A., they also caused long-lasting repercussions including drug-related ones.

The first example is the support of Manuel Noriega, who was proven to be heavily involved in the drug trafficking since i97I. In exchange for his support against Sandinistas, the ClA ignored and even at times encouraged Noriega's services for drug cartels, which included providing safe havens for drug lords, laundering their dirty money and recruiting pilots. The United States turned on him only after discover- 
ing that Noriega had been working for both parties, providing valuable intelligence to the Cubans and Sandinistas. Interestingly, the intensity of drug trafficking through Panama only increased after U.S. forces invaded the country in $1989 .{ }^{19}$

During Reagan's presidency, while Nancy Raegan was forcing the 'Just say no' zero-tolerance agenda, her husband's administration had the single-minded intention of overthrowing Sandinista forces. It gave support to the Contras, an insurgency group who lived off smuggling cocaine into the United States and happened to be a natural enemy of the Sandinista government. Eventually this excessive enthusiasm led to the Iran-Contra affair - one of the most notorious political scandals in the history of the United States alongside with Nixon's Watergate. Despite direct congressional prohibition of supplying Iran with weapons and to finance Contras, top level U.S. officials still managed to secretly sell an arsenal to Iran and redirect the earnings to support anti-Sandinista forces. When this scheme was revealed - several officials of Raegan administration took the blame in an attempt to protect the president and the investigation went no further. ${ }^{20}$ With the help of the United States, Central American cocaine smugglers managed to raise the drug supply to an unprecedented level, leading to one of the worst cocaine epidemics in the history of the United States. In 1988 the Senate Subcommittee on Terrorism, Narcotics, and International Operations finished a three-year complex investigation that basically concluded that the U.S. government knew they were directly helping forces which had been smuggling cocaine onto American soil:

There was substantial evidence of drug smuggling through the war zones on the part of individual Contras, Contra suppliers, Contra pilots, mercenaries who worked with the Contras, and Contra supporters throughout the region.... U.S. officials involved in Central America failed to address the drug issue for fear of jeopardizing the war efforts against Nicaragua.... In each case, one or another agency of the U.S. government had information regarding the involvement either while it was occurring, or immediately thereafter.... Senior U S policy makers were not immune to the idea that drug money was a perfect solution to the Contras' funding problems. ${ }^{21}$ 
The involvement of U.S. officials, the CIA in particular, into the drug trade in the Western hemisphere has been argued on other occasions as well. Perhaps the most vital aspect of drug trade is money laundering, since tons of drug-related cash are virtually impossible

CEJISS to use directly. To make this profit clean and usable, organized crime 2/20I9 sets up complex money laundering schemes - fighting this process has recently become recognized as a significant part of any successful anti-drug policy. However, the ClA was also suspected in setting up such mechanisms to clean money - to the mutual profit of both cartels and the agency itself. Just like drug lords, the CIA needs their financial resources to be clean in order to maintain the secrecy of their operations, so it comes as no surprise that several CIA-related agents were over the years noticed to be closely involved with the facilities that were known to launder money for drug-related organized crime..$^{22}$

Another allegation of CIA involvement into the drug problem is related to the controversial 'MK Ultra' project that has not been properly investigated until now due to the destruction of key evidence and important documents. But the scarce evidence that remained available makes researchers and publicists believe that the CIA took part in creating a mind-altering substance called LSD in an attempt to find ways to control human consciousness. And after having failed to achieve the primary target, the drug was leaked to the American streets due to the lack of caution from the agency and the third-party personnel involved. ${ }^{23}$

Generally, suspicious involvement of CIA former and active operatives in the drug trafficking schemes (mostly Cubans that were originally recruited and trained to fight in the Bay of Pigs) has promoted the idea that the 'War on Drugs' was primarily acting as a cover for U.S. anti-communist special interests. And even though some of these cases are now known to the public, the lack of direct proof and the privilege of secrecy that CIA is entitled to did not cause any significant repercussions for the agency itself. It would obviously be wrong to claim that the CIA singlehandedly has set up the drug trade in the Western Hemisphere - the appearance of this phenomenon is a natural consequence of globalization. However, to a certain extent the degree of high development of modern drug-related organized crime can be explained by the profound help that governmental agencies of the United States of America have intentionally or unintentionally provided during the Cold War. 
Despite the great number of authors who support CIA-alleged involvement in the drug trade, it still remains a theory that needs additional evidence. Nevertheless, the proof that already exists suggests that the 'War on Drugs' concept had little intention to prioritize fighting illicit substances. Even after the Cold War was over and there was no longer need for 'bargaining with the Devil', the concept failed to change for good. As an example, two large-scale programs called 'Plan Colombia' and 'Initiative Merida', which happened to be attempts to export the 'War on Drugs' values, did not change much in terms of instruments and ideology. Both of these programs did not achieve their primary target and caused both expert and academic communities to raise questions about the capabilities of the anti-drug U.S. policies.

Finally, the most recent failures of the 'War on Drugs' have caused the international community, which for a long time had been very supportive of such an approach, to admit that fighting drugs by force has failed. In 20II, a report from The Global Commission on Drug Policy (with the participation of former Secretary General of the United Nations Kofi Annan) openly declared: 'The global War on Drugs has failed, with devastating consequences for individuals and societies around the world. Fifty years after the initiation of the UN Single Convention on Narcotic Drugs, and 40 years after President Nixon launched the U.S. government's War on Drugs, fundamental reforms in national and global drug control policies are urgently needed.'24 This is a turning point that urges further search for new balanced approaches, which would be both more socially oriented and humane in nature. Harsh criminalization and massive incarcerations being primary principles of the 'War on Drugs' are now considered to be outdated. More and more researchers and politicians prefer to address the global drug problem through multi-level approaches that balance out law enforcement efforts with active social policies.

\section{Conclusion}

Summing up, the 'War on Drugs' concept was bound to fail for obvious reasons. First, its set of values has been scientifically proven to be unfit to deal with proliferating drug trade from the start. Instead of providing a multi-level approach, the evident prevalence of a force-based toolset led only to the skyrocketing rates of the incarcerated population, while the vital parts of the supply chains were left unharmed and demand remained equally high. Instead of helping drug addicts, high
The 'War on Drugs' Concept 
criminalization and further stigmatization have only resulted in heavily limiting their opportunities for rehabilitation and further reintegration into society. Secondly, on top of its obvious flaws we can add up the fact that the Nixon administration was using the concept for its CEJISS own quite selfish purposes, trying to forcefully control protest move2/20I9 ments in the face of upcoming elections. Third, the 'War on Drugs' was never a priority in the conditions of the Cold War. Moreover, the dominance of Washington's ideological struggle against the Soviets motivated governmental agencies, such as the CIA, to commit actions that directly or indirectly promoted the drug problem in the Western Hemisphere. With the short-term 'means to an end' tactics that have been used by the United States, the countries of the Western Hemisphere now have to deal with extremely powerful criminal organizations such as drug cartels.

This makes us consider the fact that to a certain point the degree of development of the drug trade in the Western hemisphere was caused by the absolute priority of the U.S. government to fight communism instead of focusing on illicit drug traffic. As such, the United States never stopped to consider possible destructive repercussions of their actions. These very consequences have now taken the form of extremely enduring and hard to exterminate transnational structures that consist of highly organized drug producing and trafficking crime groups. In order to successfully fight them, the international community has gradually shifted to new possibilities in the sphere of countering illicit drug-trade. However, for a long period of time these efforts were blocked by the detrimental heritage of the 'War on Drugs'.

Unlike most of the research in this field (P.D. Scott, M. Otterman, C. Castillo etc.), the authors of the article come to a conclusion that not only was the concept of the 'War on Drugs' ineffective and even malicious in the recent past, but its heritage still hinders the development of breakthrough innovative approaches to countering drug traffic throughout the region. To ensure that modern anti-drug policies succeed in adapting to current practical realities, academic and expert communities should move away from such outdated concepts to a more progressive and balanced approach towards the global drug problem, including its profound social basis and necessity for more humanism towards the addicts. But on top of that, it is vital for United States of America to finally admit that the 'War on Drugs' has not paid off the way it was designed and financed. 
Arkadiy AlekseEvich Eremin is affiliated with the department of theory and history of international relations of the Peoples' Friendship University of Russia and can be reached at eremin_aa@pfur.ru.

Arkadiy

Alekseevich

Oleg Konstantinovich Petrovich-Belkin is affiliated with the Eremin department of theory and history of international relations of the Peoples' Friendship University of Russia and can be reached at petrovioleg@yandex.ru.

Oleg

Konstantinovich

Petrovich-Belkin

\section{Notes}

I Kozel, N. J., Adams, E. H. (1990) Cocaine Use in America: Epidemiological and Clinical Perspective, Maryland, 3rd edition. Department of Health and Human Services (DHHS). URL: http://archives.drugabuse.gov/pdf/ monographs/6I.pdf (accessed 20.08.20I7).

2 War on Drugs. Report of Global Commission on Drug Policy, 20II. URL: http://www.globalcommissionondrugs.org/wp-content/uploads/2012/o3/ GCDP_WaronDrugs_EN.pdf (accessed 23.08.2017).

3 Eremin A.A., Eremina M.S., Abdurashitova E. (20I7) 'The input of resolution A/RES/S-30/I in the formation of the new global anti-drug approaches,' Vestnik RUDN. International Relations I7 (I), 95-IIO.

4 Edwards L., Edwards E. (2016). A Brief History of the Cold War. Washington D.C., Regnery History. P.272.

5 National security strategy of the United States. The White House, I987. URL: https://babel.hathitrust.org/cgi/ pt?id=uiug.30II2I05I96684;view=Iup;seq=3 (accessed 29.08.20I7).

6 National security strategy of the United States. The White House, I988. URL: http://nssarchive.us/NSSR/I988.pdf (accessed 02.09.20I7).

7 Martynov B.F. (ed.) (2017), Contemporary organized crime in Latin America and Caribbean, Moscow, Ves Mir Publishers. P. 270.

8 World Drug Report 20I6. United Nations Office on Drugs and Crime. URL: http://www.unodc.org/doc/wdr2oI6/WORLD_DRUG_REPORT_2oI6_ web.pdf (accessed 22.08.20I7).

9 Werb, D. et al. (2013) 'The Temporal Relationship between Drug Supply Indicators: an Audit of International Government Surveillance Systems,' BMJ Open, 3 (9).

Io National Survey on Drug Use and Health. Substance Abuse and Mental Health Services Administration, 20I6. URL: https:/www.samhsa.gov/ data/sites/default/files/NSDUH-FFRI-20I6/NSDUH-FFRI-2oi6.htm (accessed 27.08.20I7).

II Keefe, P.R. (20I2) 'Cocaine Incorporated,' New York Times Magazine. NY, New York Times Company.

I2 Alexander, M. (2010) 'Obama’s Drug War', The Nation. URL: https://www. thenation.com/article/obamas-drug-war/ (accessed 21.08.20I7). 
I3 Alexander, M. (2014) A System of Racial and Social Control. Interview to Frontline PBS, 20I4. URL: http://www.pbs.org/wgbh/frontline/article/ michelle-alexander-a-system-of-racial-and-social-control/ (accessed 22.08.20I7).

I4 Stevens, Alex et.al. (2007) Prisons and Drugs: A global review of

CEJISS

$2 / 20 I 9$ incarceration, drug use and drug services. The Berkley Foundation Drug Policy Programme.

I5 Marihuana: A Signal of Misunderstanding. National Commission on Marihuana and Drug Abuse, I937. URL: https://www.jstor.org/ stable/795372 (accessed 31.08.2017).

I6 Castillo C. (1994). Powderburns: Cocaine, Contras, and the Drug War. Oakville, Mosaic Press, P.I26.

I7 Baum, D. (2016) 'Legalize It All', Harper's Magazine. Harper's Magazine Foundation.

I8 The War on marijuana in white and black. American Civil Liberties Union (ACLU), 20I3. URL: https://www.aclu.org/issues/mass-incarceration/ smart-justice/war-marijuana-black-and-white (accessed 24.08.20I7).

I9 Dinges, J. (I99I). Our Man in Panama. NY, Random House, P.420.

20 Gates, R. (2006) The Iran-Contra Affair 20 Years On. Washington D.C, The National Security Archive.

2I Drugs, Law Enforcement and Foreign Policy. Report of the Senate Committee on Foreign Relations, Subcommittee on Terrorism, Narcotics and International Operations, I989. URL: https://babel.hathitrust.org/cgi/ pt?id=pst.ooooI4976r24;view=Iup;seq=3 (accessed 2I.08.20I7).

22 Wright, E. (2012). How to Get Away with Murder in America. NY, Byliner Inc., P.I3o.

23 Otterman, M. (2007) American Torture: From the Cold War to Abu Ghraib and Beyond. Melbourne University Publishing, p. 24.

24 War on Drugs. Report of Global Commission on Drug Policy, 20II. URL: http://www.globalcommissionondrugs.org/wp-content/uploads/2012/03/ GCDP_WaronDrugs_EN.pdf (accessed 23.08.20I7).

25 Bobo, Lawrence D., and Victor Thompson. 'Unfair by design: The war on drugs, race, and the legitimacy of the criminal justice system,' Social Research: An International Quarterly 73.2 (2006): 445-472.

26 Booth, M. (2004) Cannabis: A History. NY, Thomas Dunne Books/St. Martin's Press.

27 Chin, Gabriel J. 'Race, the war on drugs, and the collateral consequences of criminal conviction,' Journal Gender Race \& Just. 6 (2002): 253.

28 De Mesquita B.B. (20II) The Dictator's Handbook: Why Bad Behavior is Almost Always Good Politics. NY, Random House. P272.

29 O'Malley P., Atwood P.L., Peterson P. (eds.) (2006), Sticks \& Stones: Living with uncertain wars, University of Massachusetts Press, P.3oI.

30 Osorio, Javier. 'The contagion of drug violence: spatiotemporal dynamics of the Mexican war on drugs,' Journal of Conflict Resolution, Vol. 59., Issue 8 (2015): I403-I432.

3I Provine, Doris Marie. Unequal under law: Race in the war on drugs. University of Chicago Press, 2008.

32 Regilme, Salvador Santino Fulo. 'Does US Foreign Aid Undermine Human Rights? The 'Thaksinification' of the War on Terror Discourses and the Human Rights Crisis in Thailand, 200I to 2006, Human Rights Review (20I8): I-23. 
33 Regilme Jr, Salvador Santino Fulo. 'A human rights tragedy: Strategic localization of US foreign policy in Colombia,' International Relations (2018): 00471I7818777830.

34 Scott, P.D. 'Cocaine, the contras, and the United States: How the U.S. government has augmented America's drug crisis,' Crime, Law and Social Change, Vol. I6, 97-I3I.

35 Scott, P.D. (2009) 'Obama and Afghanistan: America's drug-corrupted war, Global research. URL: https://www.infowars.com/obama-andThe 'War on Drugs' Concept afghanistan-americas-drug-corrupted-war/ (accessed 23.08.20I7).

36 Scott, P.D., Marshal J. (I99I) Cocaine Politics. Los Angeles, University of California Press, I72-I85.

37 Scott, P.D. (20I2) 'Launching the U.S. terror war: The CIA, 9\II, Afghanistan and Central Asia,' The Asia-Pacific Journal: Japan Focus. Vol Io, Issue I2, No.3. URL: http://apjjf.org/-Peter-Dale-Scott/3723/article.pdf (accessed 23.08.20I7).

38 Statistics \& Facts. Drug Enforcement Administration. URL: https://www. dea.gov/resource-center/statistics.shtml (accessed 22.08.20I7). 